\section{Capdeville, Augusto}

\author{
Benjamín Ballester Riesco ${ }^{1}$ and \\ Alexander San Francisco Araya ${ }^{2}$ \\ ${ }^{1}$ UMR 7041 ArScAN, Équipe Ethnologie \\ Préhistorique, Université Paris 1 Panthéon \\ Sorbonne, Paris, France \\ ${ }^{2}$ Museo Augusto Capdeville Rojas de Taltal \\ associated research, Taltal, Chile
}

\section{Basic Biographical Information}

Augusto Capdeville (1864-1932) was a Chilean archaeologist who discovered the archaeological sites of Taltal, in the north of Chile. This launched prehistorians' interest on this zone and contributed to national and international debates on the origins of the American Man.

Augusto Henri Capdeville Rojas was born in Santiago, on August 20, 1864. His father arrived from Avignon to Valparaiso in 1860, where he met Rafaela Rojas, with whom he had two children, Augusto and Ramón, and a very short marriage. At the age of 3, Augusto loses his mother as a result of tuberculosis, so they move to Talca, in the central Southern part of the country, where they form an extended family of ten brothers and sisters with their father's new wife, Clodomira Miranda. By then, his father had become a prominent business man in the tailoring and hat industry, so the family enjoyed a considerably comfortable life (Looser 1932; Mostny 1964; Núñez 2008).

He completed his studies in Humanities in the Lyceum of Talca and later in the National Institute of Santiago, where he graduated in 1883. Between 1884 and 1885, he studied Law and Medicine at the same time, a project he had to abandon after his father's death and lack of economic support. That is why he had to work as Chief of the Bulletin and then Archivist in the Ministry of Industries and Public Works of Chile; there he meets the President of the country, José Manuel Balmaceda. In 1895 , he was transferred to Constitución seaport with the position of Warehouse Guard of the same ministry, where he wrote his first publication (Capdeville 1893).

In 1897 , he is transferred to the saltpeter port of Taltal, even though he had asked to be sent to Chañaral, the nearest town to the South. There, he will stay for more than 27 years, together with his wife, Matilde Celis, with whom he has a big family. In Taltal, he starts working as a saltpeter weigher, then Customs Mayor, and finally becomes Chief of Security, a post he keeps till the rest of his stay at the port.

Even with the limited salary of a civil servant and being in charge of seven children, Capdeville devoted a large part of his income to the purchase of books and scientific journals, eventually setting up a huge library specialized in American archaeology and ethnology. Later he concentrates on his own studies and explorations: the first of his archaeological discoveries in Taltal is carried out 
in September 18, 1914; those go on ceaselessly for almost 10 years (Latcham 1939).

Capdeville collected surface material and excavated about 60 archaeological sites in Taltal, between Caleta Agua Dulce in the North and Caleta Esmeralda in the South, an extension of more than $190 \mathrm{~km}$ of coastline along the Atacama Desert coast. His works, with highly detailed field records and highly detailed and subtle drawings, showed the pre-Hispanic occupational intensity of this area and the craftsmanship, social, and cultural virtues of its fishermen. He shared his findings through letters with some of the most prestigious archaeologists, anthropologists, and historians of the beginning of the century, such as Max Uhle, who considered himself as his disciple, Aureliano Oyarzún, Carlos Porter, Jose Toribio Medina, Jacinto Jijón and Caamaño, Walter Looser, Ricardo Latcham, Eric Boman, Carlos Ameghino, Salvador Debenedetti, and Ramón Laval (Oyarzún 1916; Uhle 1916; Mostny 1964).

In 1916, Capdeville enters the Chilean Society of History and Geography as a member, and in 1920 he became a Corresponding Member of the Ecuadorian Society of Historical Studies. This membership was achieved thanks to Max Uhle, with whom, during these years, he kept a close communication. In addition, it is the same German scholar who encouraged him to publish his first archaeological works in Ecuador's Bulletin of the National Academy of History between 1921 and 1923. In 1924, he leaves Taltal for health problems to settle in San Antonio, a seaport he would leave 2 years later after his retirement in Quillota City. He passes away in Viña del Mar, on September 21, 1932.

Augusto Capdeville's works placed the unknown town of Taltal in the map of the world archaeology, as well as the old inhabitants of the Atacama Desert littoral in the history of the South American inhabitants. All this took place, years ahead archaeology was consolidated in scientific

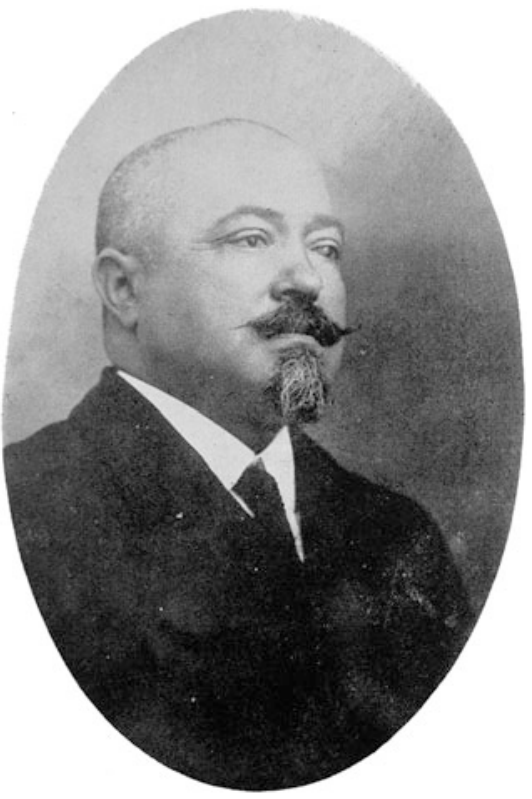

Capdeville, Augusto, Fig. 1 Augusto Capdeville Rojas

societies and universities, during a phase of the founding of Americanist studies and pre-Columbian past concerns. This is the time when a passionate customs officer became a referent among some of the most prestigious scientists, naturalists, and historians devoted to the South Pacific.

Taltal attracted some prominent researchers; they wanted to personally visit these magnificent sites and make their own excavations, such as Max Uhle in 1916, Ricardo Latcham in 1924, or Junius Bird in 1941-1942. Today, almost a century after his explorations and discoveries, he is still the most important and remembered Taltal archaeology scholar, the foundation of later investigations, and the one who has probably best described the past life of the area's inhabitants. These days, the Taltal Museum bears his name and holds part of his archaeological collections and field notebooks, guarding his archive as a legacy (Figs. 1, and 2). 


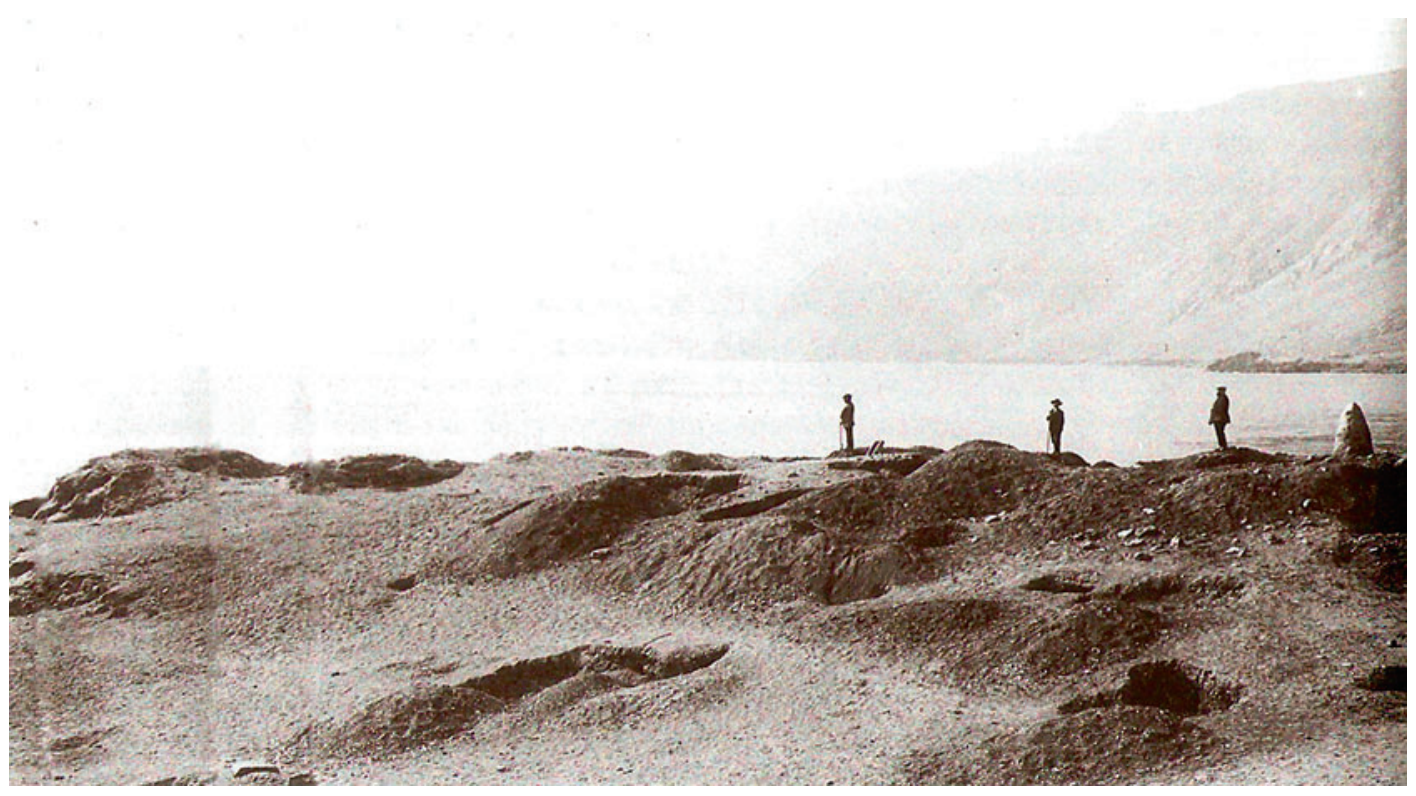

Capdeville, Augusto, Fig. 2 Archaeological work in Morro Colorado Site, Taltal

\section{References}

Capdeville, A. 1893. El Puerto de Constitución: ventajas que se obtendrán con su mejora (Estudio Estadístico). Boletín de la Sociedad de Fomento Fabril: 467-482.

Latcham, R. 1939. La edad de piedra en Taltal. Boletín del Museo Nacional de Historia Natural 17: 3-32.

Looser, G. 1932. El arqueólogo Don Augusto Capdeville. Boletín de la Biblioteca Nacional 3 (18): 244-246.
Mostny, G. 1964. Arqueología de Taltal: epistolario de Augusto Capdeville con Max Uhle y otros. Santiago: Fondo Histórico y Bibliográfico José Toribio Medina.

Núñez, P. 2008. Augusto Henri Capdeville Rojas. Tópicos de Chile y su época. Taltalia 1: 11-20.

Oyarzún, A. 1916. La estación paleolítica de Taltal. Revista Chilena de Historia y Geografia 19 (23): 48-59.

Uhle, M. 1916. Sobre la Estación Paleolítica de Taltal. Revista Chilena de Historia y Geografia 20 (24): 47-66. 